\title{
New retrieval of $\mathrm{BrO}$ from SCIAMACHY limb: an estimate of the stratospheric bromine loading during April 2008
}

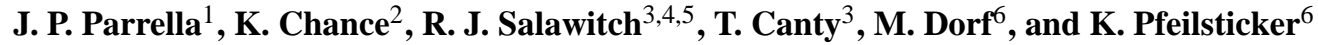 \\ ${ }^{1}$ School of Engineering and Applied Sciences, Harvard University, Cambridge, MA, USA \\ ${ }^{2}$ Harvard-Smithsonian Center for Astrophysics, Cambridge, MA, USA \\ ${ }^{3}$ Department of Atmospheric and Oceanic Science, University of Maryland, College Park, MD, USA \\ ${ }^{4}$ Department of Chemistry and Biochemistry, University of Maryland, College Park, MD, USA \\ ${ }^{5}$ Earth System Science Interdisciplinary Center, University of Maryland, College Park, MD, USA \\ ${ }^{6}$ Institut für Umweltphysik, University of Heidelberg, Heidelberg, Germany
}

Correspondence to: J. P. Parrella (parrella@ post.harvard.edu)

Received: 27 September 2012 - Published in Atmos. Meas. Tech. Discuss.: 30 October 2012

Revised: 16 June 2013 - Accepted: 15 July 2013 - Published: 7 October 2013

\begin{abstract}
We present a new retrieval of stratospheric $\mathrm{BrO}$ (bromine monoxide) from channel 2 SCIAMACHY (SCanning Imaging Absorption spectrometer for Atmospheric CHartographY) limb observations. Retrievals are shown to agree with independent balloon observations to within one standard deviation of the retrieval noise. We retrieve $\mathrm{BrO}$ profiles for all of April 2008, and apply simulated $[\mathrm{BrO}] /\left[\mathrm{Br}_{\mathrm{y}}\right]$ (bromine monoxide: stratospheric inorganic bromine) ratios to estimate the stratospheric $\mathrm{Br}_{\mathrm{y}}$ loading. We find $23.5 \pm 6 \mathrm{ppt} \mathrm{Br}$, suggesting $7 \mathrm{ppt} \mathrm{Br}$ from short-lived bromocarbons to be at the high end of the current best estimate (3-8ppt). The $6 \mathrm{ppt} \mathrm{Br}$ uncertainty estimate is dominated by the $21 \%$ uncertainty in the simulated $[\mathrm{BrO}] /\left[\mathrm{Br}_{\mathrm{y}}\right]$ ratio due to propagation of errors from the underlying chemical kinetics.
\end{abstract}

\section{Introduction}

Bromine radicals $\left(\mathrm{BrO}_{\mathrm{x}} \equiv \mathrm{Br}+\mathrm{BrO}\right)$ are important catalysts for ozone destruction in the stratosphere (Montzka et al., 2011). Through synergistic catalytic cycles with $\mathrm{ClO}$ and $\mathrm{HO}_{2}$, bromine contributes roughly 30 to $50 \%$ of the seasonal ozone loss in the polar stratosphere (Anderson et al., 1989; Frieler et al., 2006) and between $10-50 \%$ of the ozone loss in the midlatitude lower stratosphere (Garcia and Solomon, 1994; Wennberg et al., 1994; Salawitch et al., 2005). Stratospheric total inorganic bromine, $\mathrm{Br}_{\mathrm{y}}\left(\mathrm{Br}_{\mathrm{y}} \equiv \mathrm{Br}+\mathrm{BrO}+\right.$
$\mathrm{Br}_{2}+\mathrm{BrCl}+\mathrm{HBr}+\mathrm{HOBr}+\mathrm{BrNO}_{3}$ ), originates from photochemical destruction of brominated organic source gases (Montzka et al., 2011) and possibly through the direct transport of $\mathrm{Br}_{\mathrm{y}}$ from the troposphere (Laube et al., 2008). The accurate characterization of the stratospheric $\mathrm{Br}_{\mathrm{y}}$ loading is important to understanding stratospheric ozone chemistry and trends (Salawitch et al., 1993, 2005; Wennberg et al., 1994; Gao et al., 1997), as well as to interpreting nadir $\mathrm{BrO}$ satellite observations (Salawitch et al., 2010; Theys et al., 2011; Choi et al., 2012).

However, quantifying the bromine budget remains difficult due to uncertainties in measurements of $\mathrm{BrO}$ (bromine monoxide) and organic bromine source gases, as well as an incomplete understanding of the transport to the stratosphere of bromine source gases (Salawitch et al., 2010; Montzka et al., 2011). Limb geometry satellite observations of $\mathrm{BrO}$ serve as important constraints on $\mathrm{Br}_{\mathrm{y}}$ in the middle and upper stratosphere, but yield a large range of estimates, between 16.5-29 ppt for $\mathrm{Br}_{\mathrm{y}}$ (Sinnhuber et al., 2005; Sioris et al., 2006; Kovalenko et al., 2007; McLinden et al., 2010; Montzka et al., 2011). Here, we retrieve stratospheric profiles of $\mathrm{BrO}$ for April 2008 from near-UV SCIAMACHY (SCanning Imaging Absorption spectrometer for Atmospheric CHartographY) limb observations and estimate stratospheric $\mathrm{Br}_{\mathrm{y}}$ using a photochemical model to infer $\mathrm{Br}_{\mathrm{y}}$ from $\mathrm{BrO}$. April 2008 was chosen to make use of detailed information on stratospheric meteorology and composition in the Northern Hemisphere available through the 
START08 (Stratosphere-Troposphere Analyses of Regional Transport) and ARCTAS (Arctic Research of the Composition of the Troposphere from Aircraft and Satellites) field campaigns, important for modeling the $[\mathrm{BrO}] /\left[\mathrm{Br}_{\mathrm{y}}\right]$ ratios (Salawitch et al., 2010).

The organic source gases for stratospheric $\mathrm{Br}_{\mathrm{y}}$ include $\mathrm{CH}_{3} \mathrm{Br}$ (atmospheric methyl bromide) and halons (bromofluorocarbons), which have photochemical lifetimes between 8 months and $65 \mathrm{yr}$ (Wamsley et al., 1998), and the brominated organics commonly referred to as very short-lived substances (VSLS), which have photochemical lifetimes $<6$ months (Montzka et al., 2011). $\mathrm{CH}_{3} \mathrm{Br}$ and halons contribute $\sim 16.5$ ppt of $\mathrm{Br}_{\mathrm{y}}$ to the stratosphere (Montzka et al., 2011). $\mathrm{CH}_{3} \mathrm{Br}$ has many natural and anthropogenic sources, the largest of which are the ocean and fumigation, respectively. Halons have anthropogenic origin, and are most widely used as fire retardants (Montzka et al., 2011). The contribution from VSLS to stratospheric $\mathrm{Br}_{\mathrm{y}}$ is less well-known. The VSLS are of marine biogenic origin and most VSLS bromine is in the form of $\mathrm{CHBr}_{3}$ and $\mathrm{CH}_{2} \mathrm{Br}_{2}$, with smaller contributions from other species, including $\mathrm{CHBrCl}_{2}, \mathrm{CHBr}_{2} \mathrm{Cl}$, and $\mathrm{CH}_{2} \mathrm{BrCl}$ (Carpenter and Liss, 2000; Hossaini et al., 2012). Best estimates from observations and modeling suggest an additional 2-8 ppt $\mathrm{Br}_{\mathrm{y}}$ is present in the stratosphere beyond the contributions from $\mathrm{CH}_{3} \mathrm{Br}$ and halons (Montzka et al., 2011; Brinckmann et al., 2012). VSLS are thought to close this budget, possibly with contributions from the direct transport of tropospheric $\mathrm{Br}_{\mathrm{y}}$.

Here, we present a new retrieval algorithm for $\mathrm{BrO}$ profile inversion from SCIAMACHY limb near-UV measurements. We compare our results with several independent balloon observations and characterize our retrieval process. The algorithm is then used to retrieve $\mathrm{BrO}$ from all available SCIAMACHY limb data in April 2008. Bry estimates are made for each retrieved profile by applying $[\mathrm{BrO}] /\left[\mathrm{Br}_{\mathrm{y}}\right]$ ratios that are simulated with a stratospheric chemistry model for SCIAMACHY overpass conditions.

\section{SCIAMACHY}

The SCanning Imaging Absorption spectrometer for Atmospheric CHartographY (SCIAMACHY) is a passive remote sensing spectrometer mounted on the starboard side of the European Space Agency (ESA) Envisat satellite. It has 8 spectral channels with coverage from near ultraviolet (UV) to near infrared (IR) (213-2386 nm). Observations are taken in alternating viewing geometries, limb and nadir, as the satellite travels in a low-earth polar orbit at $\sim 800 \mathrm{~km}$ in altitude, with a local overpass time of $\sim 10: 30 \mathrm{LT}$ in the descending node. We use level 1 data from channel 2, which covers $300-412 \mathrm{~nm}$, where $\mathrm{BrO}$ has well-defined vibrational band structure in the $\mathrm{A}^{2} \Pi_{3 / 2} \leftarrow \mathrm{X}^{2} \Pi_{3 / 2}$ electronic transition (Wilmouth et al., 1999).

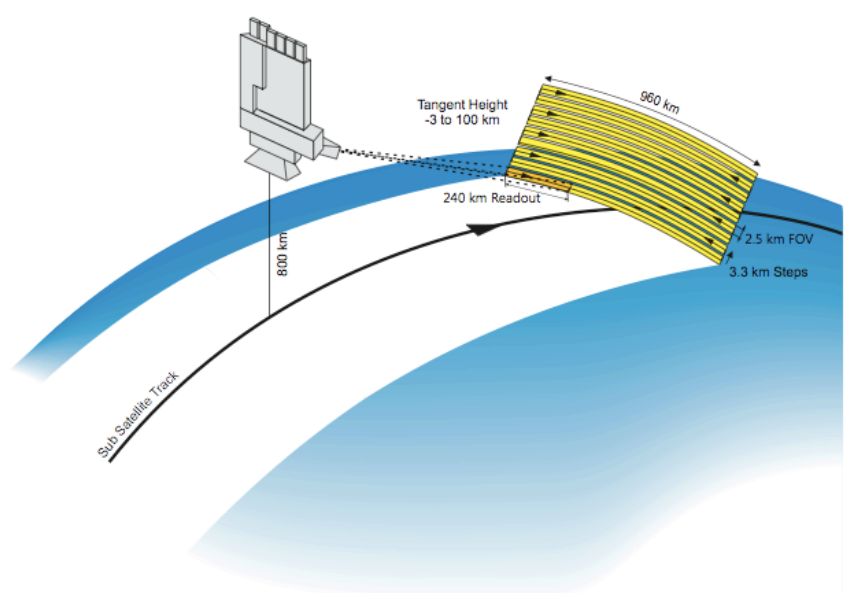

Fig. 1. Illustration of SCIAMACHY operations and spatial resolution. Plot printed with permission of S. Noël, University of Bremen, Germany; figure from Rozanov et al. (2011).

Figure 1 illustrates the typical operation and spatial resolution of SCIAMACHY, which covers 14.3 orbits per day and achieves global coverage for both limb and nadir in 6 days (Gottwald et al., 2011). Each orbit contains about 30 limb scans, during which the instrument registers spectra scanning sequentially from Earth's surface up to $\sim 100 \mathrm{~km}$ in altitude. Vertical stepping is performed at $3.3 \mathrm{~km}$ resolution, with a $2.5 \mathrm{~km}$ vertical field of view (FOV). For each tangent height $(\mathrm{TH})$, the instrument records between 1 and 4 adjacent azimuthal scenes, depending on the planned signal integration time. This results in a horizontal pixel resolution between 240 and $960 \mathrm{~km}$. In this work, we average the spectra along the azimuthal direction to improve the observation signal-to-noise ratio (Sioris et al., 2006). Thus, the horizontal resolution of each retrieved profile in our work is $960 \mathrm{~km}$.

SCIAMACHY data must first be converted from detector units into absolute radiances using a standard tool provided by ESA (Gottwald et al., 2011). This tool calibrates the observations for instrumental effects such as the memory effect, leakage current, pixel-to-pixel gain, etalon, and stray light. Beyond the standard processing, several additional calibrations must be performed to properly deconvolve overlapping spectral features within the observed radiances. One calibration step is shifting in wavelength registration, which is mostly due to the Doppler effect but also to the instrument's sensitivity to temperature (Caspar and Chance, 1997). Second, the instrument slit function must be accurately characterized. In channel 2 , the slit function can be accurately represented as Gaussian, typically with a full width at half the maximum (FWHM) of $\sim 0.2 \mathrm{~nm}$ (Sioris et al., 2006). The sampling frequency in this channel is $\sim 0.11 \mathrm{~nm}$, and so the signal is undersampled, requiring that aliasing be taken into account. Sampling a Gaussian signal at twice the FWHM amounts to $1.5 \%$ error (Chance et al., 2005), significantly larger than the typical $10^{-4}$ to $10^{-3}$ slant optical depths 
observed for BrO. We correct for this aliasing error by calculating the difference between fully sampled and undersampled versions of a high resolution Fraunhoffer spectrum, and including these error spectra as basis functions during spectral fitting of the earthshine radiances (Chance et al., 2005). All calibrations used in this work are described in Sects. 3 and 3.1.

\section{Methods}

We use version 7.04 of SCIAMACHY level 1 limb data, and apply all available calibrations, $0-7$, as well as the M-factor corrections that account for the wavelength-dependent pixel degradation the instrument has undergone since 2002 (http:// www.iup.uni-bremen.de/sciamachy/mfactors/). Calibrations 6 and 7 deal with polarization and absolute radiance corrections respectively, and have been excluded from previous SCIAMACHY BrO retrievals due to the potential for introducing artificial polarization features (G. Brizzi and A. Rozanov, personal communication, 2012). However, comparing the residuals obtained by fitting spectra treated with all calibrations against the fitting residuals from spectra excluding calibrations 6 and 7, we find no statistical difference in our results. This is likely due to the effectiveness of our low tangent height common mode basis function and upper tangent height basis functions, described in Sect. 3.1, at removing instrumental artifacts from the residuals. We note that these two basis functions were important for improving our fitting statistics regardless of the set of calibrations treated. Chanel 2 is processed for $\mathrm{BrO}$ spectral information. Channels 4 and 6 are processed for cloud flagging following methods described by von Savigny et al. (2005). For all spectral data used in this work, the azimuthal pixels for each tangent height in a limb scan are averaged to improve signalto-noise.

The retrieval algorithm that we developed can be separated into two main parts: (1) a spectral fitting step, where slant column densities (SCD) of $\mathrm{BrO}$ are determined from the level 1 SCIAMACHY data, and (2) an inversion step where a radiative transfer model is used to fit profiles of $\mathrm{BrO}$ number density to the slant columns by Gauss-Newton optimal estimation (Rodgers, 2000). This two-step strategy is similar to that used by Kühl et al. (2008), using SCIAMACHY, and McLinden et al. (2010), using OSIRIS, for BrO limb observations.

All spectra with tangent heights $(\mathrm{TH})$ between $6 \mathrm{~km}$ and $42 \mathrm{~km}$ are considered for use within each profile retrieval. Cloudy pixels are first identified within this altitude range by calculating the color index ratio described by von Savigny et al. (2005). In this approach, radiances are first integrated in $10 \mathrm{~nm}$ bands centered about $\lambda_{1}=1090 \mathrm{~nm}$ and $\lambda_{2}=750 \mathrm{~nm}$, and the ratio of these two radiances, $R\left(\mathrm{TH}_{i}\right)=$ $I\left(\lambda_{1}, \mathrm{TH}_{i}\right) / I\left(\lambda_{2}, \mathrm{TH}_{i}\right)$, is calculated for each tangent height.
The color index ratio is then

$\Theta\left(\mathrm{TH}_{i}\right)=R\left(\mathrm{TH}_{i}\right) / R\left(\mathrm{TH}_{i+1}\right)$,

where $\mathrm{TH}_{i+1}$ is the observation directly above $\mathrm{TH}_{i}$ in that limb scan. Clouds are identified where $\Theta\left(\mathrm{TH}_{i}\right)>1.3$ (von Savigny et al., 2005). All tangent height spectra above the highest registered cloudy scene in the $6-42 \mathrm{~km}$ retrieval range are passed to the spectral fitting routine. The lowest TH cloud-free spectrum is used for calculating a pseudoabsorber that accounts for instrumental artifacts following Sioris et al. (2006). We describe this in Sect. 3.1. The remaining cloud-free spectra are fit for BrO SCDs. Fitted slant columns are excluded from the inversion step if the spectrum is fit to a root mean square (RMS) of greater than $10^{-3}$, when noise often exceeds the $\mathrm{BrO}$ signal.

Spectral fitting is performed for each tangent height separately in a given limb scan using the ELSUNC nonlinear least squares algorithm (Lindström and Wedin, 1988), the same fitting used in the operational $\mathrm{BrO}$ and $\mathrm{H}_{2} \mathrm{CO}$ retrievals for the NASA Ozone Monitoring Instrument (OMI). The least squares routine uses a basic Gauss-Newton method to search the solution space, but speeds convergence by implementing a truncated QR-method when far from the minimum and an undamped Newton method when the solution is highly curved close to the minimum (Lindström and Wedin, 1988). Each radiance spectrum is fit against an observed radiance reference, $I_{0}$, in a modified Beer's law framework. The radiance reference must represent local conditions and is typically taken as a high tangent height $(>30 \mathrm{~km})$ spectrum in that limb scan (Haley et al., 2004; Rozanov et al., 2005, 2011; Sioris et al., 2006; McLinden et al., 2010).

We generate radiance references for each limb scan by summing tangent height spectra between 42 and $70 \mathrm{~km}$ following Sioris et al. (2006). Before applying $I_{0}$ in Beer's law fitting, the width of the instrument slit function and shifting in the wavelength registration must first be characterized. We find these parameters to be stable over the period of one SCIAMACHY orbit. Thus, we select one radiance reference spectrum from the middle of each orbit and fit against a high-resolution synthetic solar spectrum (Chance and $\mathrm{Ku}-$ rucz, 2010) for the instrument slit width and shift parameters (Caspar and Chance, 1997). These correction parameters are then applied in all of the fitting procedures for each respective orbit.

\subsection{Fitting BrO slant columns}

After identifying cloud-free spectra and determining the instrument slit width and wavelength shift, we then fit each tangent height spectrum in a limb scan independently against its radiance reference. We find an optimal wavelength fitting window of 338-356.2 nm for BrO from SCIAMACHY limb, consistent with Rozanov et al. (2011). This yielded minimum fitting residuals and cross-correlations between the overlapping spectral absorbers and other basis functions. Residuals 
were comparable for the 344-360 nm fitting window used by Sioris et al. (2006) for SCIAMACHY limb BrO observations; however, we found that slant column amounts of $\mathrm{BrO}$ to be unstable through orbits when applying the latter window. This may be due to instrumental artifacts in SCIAMACHY channel 2 observations (De Smedt et al., 2004). More work is necessary to fully resolve this discrepancy. Here, we apply the $338-356.2 \mathrm{~nm}$ fitting window in all retrievals.

Tangent height spectra are modeled for nonlinear least squares fitting with the modified Beer's law approximation shown in Eq. (2). The fitting method follows Chance (1998) with several modifications for SCIAMACHY limb described by Sioris et al. (2006). The nonlinear least squares is performed using ELSUNC (Sect. 3) and involves simulating the radiance vector, $\boldsymbol{I}_{\text {sym }}$, and iteratively adjusting each parameter until the residuals are minimized, assuming Gaussian statistics. $\boldsymbol{I}_{\text {sym }}$ is written as

$$
\begin{aligned}
& \boldsymbol{I}_{\text {sym }}=\left[A_{1} \times I_{0} \times \exp (B)+A_{2}\right] \times P_{1}+P_{2}, \\
& A_{1}=c+c_{\mathrm{US}_{1}} \sigma_{\mathrm{US}_{1}}+c_{\mathrm{US}_{2}} \sigma_{\mathrm{US}_{2}}+c_{\text {Ring }} \sigma_{\text {Ring }}, \\
& A_{2}=c_{\text {low }} \sigma_{\text {low }}+c_{\text {high }} \sigma_{\text {high }}, \\
& B=-\left(c_{\mathrm{BrO}} \sigma_{\mathrm{BrO}}+c_{\mathrm{O}_{3}, T_{1}} \sigma_{\mathrm{O}_{3}, T_{1}}+c_{\mathrm{O}_{3}, T_{2}} \sigma_{\mathrm{O}_{3}, T_{2}}+c_{\mathrm{NO}_{2}} \sigma_{\mathrm{NO}_{2}}\right) \\
& P_{1}=1+c_{P_{1}, 1} \lambda_{0}+c_{P_{1}, 2} \lambda_{0}^{2}+c_{P_{1}, 3} \lambda_{0}^{3} \\
& P_{2}=c_{P_{2}, 0}+c_{P_{2}, 1} \lambda_{0}+c_{P_{2}, 2} \lambda_{0}^{2}+c_{P_{2}, 3} \lambda_{0}^{3} \\
& \lambda_{0}=\lambda-\bar{\lambda}
\end{aligned}
$$

Here, $A_{1}$ represents a group of additive correction terms that include a 0th order albedo term (albedo), two phases of undersampling basis functions ( $\mathrm{US}_{1}$ and $\mathrm{US}_{2}$ ) to correct for spectral aliasing (Chance et al., 2005), and the Ring effect (ring) (Chance and Spurr, 1997), which is spectral structure due to rotational Raman scattering predominantly by atmospheric $\mathrm{O}_{2}$ and $\mathrm{N}_{2}$. Shifting error is accounted for by first interpolating $\boldsymbol{I}_{0}$ from the registered engineering grid to the true, shift-corrected, wavelength grid. During the fitting of tangent height spectra, the shift is allowed to optimize further so as not to reduce the degrees of freedom in the fit; adjustments are typically $<10 \%$ of the original shift parameter.

$A_{2}$ is a second group of additive pseudo-absorbers described by Sioris et al. (2006), which deal with additional instrumental artifacts, such as polarization features and dark current, that have not been completely corrected for. $\sigma_{\text {low }}$ represents the low tangent height common mode correction, and $\sigma_{\text {high }}$ is a high tangent height pseudo-absorber (Sioris et al., 2006). The low tangent height common mode is taken as the residuals from fitting the lowest cloud-free tangent height spectrum in the scan, with all other basis functions applied. The high tangent height basis function is the ratio of the lowest tangent spectrum included in the radiance reference, divided by the sum of the rest. These $A_{2}$ basis functions are not significantly correlated with $\mathrm{BrO}$, improving the fitting residuals without affecting the fitted $\mathrm{BrO}$ slant column amounts (Sioris et al., 2006). Of the two corrections, the low tangent basis function has the largest impact, while $\sigma_{\text {high }}$ only improves residuals for spectra at tangent heights $>25 \mathrm{~km}$.

$B$ represents the series of Beer's law absorbers. We treat two temperatures of ozone absorption, 203 and $243 \mathrm{~K}$. The ozone cross sections are generated from a quadratic temperature parameterization by Liu et al. (2007) based on laboratory data (Daumont et al., 1992; Brion et al., 1993; Malicet et al., 1995). The two temperatures of ozone are chosen to account for the temperature dependence of ozone absorption in the Huggins bands. We use $\mathrm{NO}_{2}$ cross sections at $220 \mathrm{~K}$ from Vandaele et al. (1998) and $\mathrm{BrO}$ cross sections at $228 \mathrm{~K}$ from Wilmouth et al. (1999). All references are stored at highresolution on vacuum wavelength grids. For fitting, the cross sections are first brought to observational resolution by convolution with the fitted Gaussian slit function for the respective orbit of data. These references are then sampled on the shift-corrected wavelength grid of the observations (Chance, 1998). The chosen set of cross sections was found to minimize the fitting RMS in our work. Tests were conducted including cross sections for the $\mathrm{O}_{2}-\mathrm{O}_{2}$ collision complex, $\mathrm{OClO}$, and additional temperatures of ozone. These did not improve the fitting RMS, as concentrations of these species were at noise level (fitted uncertainties were greater than the column amounts) and occasionally caused strong correlation with BrO SCDs.

$P_{1}$ and $P_{2}$ are 3 rd order scaling and baseline polynomials that we apply to account for the gradual spectral structures from Rayleigh and Mie scattering in the observations. The Oth order term of the scaling polynomial is fixed to 1 due to high correlation with the $A_{1}$ albedo term. The polynomial abscissas, $\lambda_{0}$, are the shift-corrected observed wavelengths, centered about the mean to reduce the dynamic range of the polynomials.

\subsection{Radiative transfer model description}

After fitting the BrO SCDs and determining standard errors, we use a forward model to translate these column amounts into vertical profiles of $\mathrm{BrO}$ number density. We use the VECTOR multiple scattering limb radiative transfer model (RTM), as described by McLinden et al. (2006) and Sioris et al. (2006). VECTOR is a 2-D pseudo-spherical model that applies successive orders of scattering to solve the Schwartzchild equation (McLinden et al., 2002). Variation in the solar zenith angle (SZA) along the limb line-of-sight is discretized into 21 segments for accuracy (Sioris et al., 2006). Refraction of tangent rays is neglected, which leads to $<0.5 \%$ error (Sioris et al., 2006). The surface albedo is assumed to be 0.3 for all modeling applications in our work; however, our limb retrievals of $\mathrm{BrO}$ are insensitive to this choice.

The model atmosphere used in VECTOR is taken from the climatological lookup table generated with the University of California, Irvine (UCI) photochemical box model (Prather, 1992; McLinden et al., 2000), as described by McLinden 
et al. (2006). $\mathrm{NO}_{2}$ and $\mathrm{BrO}$ are stored as functions of latitude ( $2.5^{\circ}$ resolution), Julian day ( 2 week resolution), altitude ( $2 \mathrm{~km}$ resolution), and SZA (34 per day). Profiles are interpolated onto the VECTOR vertical grid (1 km resolution) for the appropriate SZA to match observational conditions. The total loading of $\mathrm{Br}_{\mathrm{y}}$ to the stratosphere is assumed to be $22 \mathrm{ppt}\left(\sim 5 \mathrm{ppt}\right.$ of $\mathrm{Br}_{\mathrm{y}}$ from VSLS). Temperature and ozone for the box model and RTM are taken from zonal, monthlymean climatologies derived from sonde observations (Tarpley, 1994; McPeters et al., 2007) and air density is found assuming hydrostatic equilibrium. Though VECTOR can treat diurnal variation of $\mathrm{BrO}$ and $\mathrm{NO}_{2}$ along the line of sight (McLinden et al., 2006; Sioris et al., 2006), we neglect this to save computation time and restrict our retrievals to observations with $\mathrm{SZA}<85^{\circ}$, where the effect is less significant (McLinden et al., 2010).

For our work, VECTOR simulations are purely Rayleighscattering, with no polarization and no aerosol scattering and absorption. $\mathrm{O}_{3}, \mathrm{BrO}$, and $\mathrm{NO}_{2}$ cross-sections are preconvolved with the fitted instrument slit function to simulate the observation spectral resolution. Cross section data are the same as applied in the spectral fitting stage of our retrieval, and ozone absorption is fully temperature dependent, based on fitting against laboratory measurements (Liu et al., 2007). Radiance calculations used for the Jacobian, $\mathbf{K}$, and modeled BrO slant columns, $\boldsymbol{F}\left(x_{i}\right)$, are all simulated on $1 \mathrm{~km}$ tangent height resolution between 3 and $76 \mathrm{~km}$ tangent heights, and then are convolved in altitude with a Gaussian of $2.5 \mathrm{~km}$ full width at half-maximum to approximate the instrument fieldof-view (FOV). These spectra are interpolated to the observation TH grid, and a simulated radiance reference, $\boldsymbol{I}_{0}$, is obtained by summing the spectra between 42 and $70 \mathrm{~km}$, consistent with our observed radiance reference. The modeling of $\mathbf{K}$ and $\boldsymbol{F}\left(x_{i}\right)$ is discussed further in Sect. 3.3. The sensitivity of our retrievals to model assumptions and parameter error is discussed in Sect. 4.

\subsection{Inversion}

The inversion estimates $\mathrm{BrO}$ number density from fitted $\mathrm{BrO}$ slant columns following optimal estimation (OE), which we solve by Gauss-Newton iteration (Rodgers, 2000):

$\boldsymbol{x}_{i+1}=x_{\mathrm{a}}+\mathbf{G}_{i}\left[\boldsymbol{y}-\boldsymbol{F}\left(\boldsymbol{x}_{i}\right)+\mathbf{K}_{i} \boldsymbol{x}_{i}-x_{\mathrm{a}}\right]$,

$\mathbf{G}_{i}=\mathbf{S}_{\mathrm{a}} \mathbf{K}_{i}^{\mathrm{T}}\left(\mathbf{K}_{i} \mathbf{S}_{\mathrm{a}} \mathbf{K}_{i}^{\mathrm{T}}+\mathbf{S}_{\varepsilon}\right)^{-1}$,

$\mathbf{S}_{i+1}=\mathbf{S}_{i}-\mathbf{G}_{i}\left(\mathbf{K}_{i} \mathbf{S}_{\mathrm{a}}\right)$.

$\boldsymbol{x}_{i}$ is the state vector of $\mathrm{BrO}$ number density (molecules $\mathrm{cm}^{-3}$ ) at iteration $i, x_{\mathrm{a}}$ is the a priori profile of $\mathrm{BrO}$ taken from the UCI stratospheric model, $\boldsymbol{y}$ is the vector of fitted $\mathrm{BrO}$ slant columns (molecules $\mathrm{cm}^{-2}$ ), $\mathbf{G}$ is the gain matrix, $\mathbf{K}$ is the Jacobian, and $\boldsymbol{F}\left(x_{i}\right)$ is the vector of modeled $\mathrm{BrO}$ slant columns given $x_{i}$ as the $\mathrm{BrO}$ number density profile. The gain matrix, $\mathbf{G}$, represents the sensitivity of the inversion to the observation. The measurement error covariance matrix, $\mathbf{S}_{\varepsilon}$, is assumed to be diagonal, with diagonal elements taken as the estimated variances for the corresponding fitted $\mathrm{BrO}$ slant columns. Since the standard deviation of $\mathrm{BrO}$ profiles in the stratosphere is not well-known, we use an ad hoc regularization following McLinden et al. (2010), assuming $100 \%$ error and a correlation length of $4 \mathrm{~km}$. This allows freedom to deviate away from the a priori while suppressing wide oscillations in the non-unique solution space.

Iteration over Eq. (9) minimizes the difference between measured and modeled $\mathrm{BrO}$ slant columns and the retrieved and a priori states, assuming Gaussian error statistics. The cost function can be written as

$$
\begin{aligned}
\chi^{2} & =\left\|\mathbf{S}_{\varepsilon}^{-\frac{1}{2}}\left(\mathbf{K}_{i}\left(x_{i+1}-x_{i}\right)-\left(y-\boldsymbol{F}\left(x_{i}\right)\right)\right)\right\|_{2}^{2} \\
& +\left\|\mathbf{S}_{\mathrm{a}}^{-\frac{1}{2}}\left(x_{i+1}-x_{\mathrm{a}}\right)\right\|_{2}^{2},
\end{aligned}
$$

where $\|\boldsymbol{r}\|_{2}=\left(r_{1}^{2}+r_{2}^{2}+\ldots+r_{n}^{2}\right)^{\frac{1}{2}}$ is the L2-norm of a residual vector $\boldsymbol{r}$ of length $n$. Convergence is met when the change in $\chi^{2}$ is less than $1 \%$. If convergence is not met within 8 iterations, the inversion is terminated.

Calculations of $\mathbf{K}$ and $\boldsymbol{F}\left(x_{i}\right)$ follow the methods of Haley et al. (2004) and McLinden et al. (2010) with several minor differences. In this approach, $\mathbf{K}$ is a slant column Jacobian and is approximated using radiative transfer calculations at two wavelengths, $\lambda_{\text {on }}=349.01 \mathrm{~nm}$ and $\lambda_{\text {off }}=346.74 \mathrm{~nm}$, that correspond to a peak and trough of $\mathrm{BrO}$ absorption in the middle of our spectral fitting window. First, VECTOR is used to calculate line-of-sight radiances, assuming single scattering. Then, we apply Beer's law to approximate the BrO slant column for the $i$ tangent height:

$\mathrm{SCD}_{i}^{\mathrm{BrO}}=\frac{\ln \left(\frac{I_{0}\left(\lambda_{\text {off }}\right)}{I_{i}\left(\lambda_{\text {off }}\right)}\right)-\ln \left(\frac{I_{0}\left(\lambda_{\text {on }}\right)}{I_{i}\left(\lambda_{\text {on }}\right)}\right)}{\sigma_{\mathrm{BrO}}\left(\lambda_{\text {off }}\right)-\sigma_{\mathrm{BrO}}\left(\lambda_{\text {on }}\right)}$,

where $\sigma^{\mathrm{BrO}}$ are the $\mathrm{BrO}$ cross sections (Haley et al., 2004; McLinden et al., 2010). $\mathbf{K}$ is then the sensitivity of $\mathrm{SCD}_{i}^{\mathrm{BrO}}$ to $\mathrm{BrO}$ number densities in the retrieved profile

$\mathbf{K}=\frac{\partial \boldsymbol{F}(x)}{\partial x}$.

It is calculated by finite differencing:

$K(i, j) \approx \frac{\mathrm{SCD}_{i}^{\mathrm{BrO}}\left(x^{\prime}\right)-\mathrm{SCD}_{i}^{\mathrm{BrO}}(x)}{x^{\prime}\left(z_{j}\right)-x\left(z_{j}\right)}$.

$x\left(z_{j}\right)$ is the number density of $\mathrm{BrO}$ at altitude $z_{j}$, and $x^{\prime}\left(z_{j}\right)$ is that concentration perturbed by $5 \%$. For each limb scan retrieved, we calculate $\mathbf{K}$ for the a priori profile only and apply it for all OE iterations to save computation time. Recalculating $\mathbf{K}$ at each iteration was found to change the a posteriori, $\hat{x}$, by $<1 \%$.

Since the two-wavelength approximation is inadequate for calculating $\boldsymbol{F}\left(x_{i}\right)$ (Haley et al., 2004), we generate the modeled $\mathrm{BrO}$ slant columns by fitting simulated radiance spectra generated by VECTOR for each tangent height. Spectra spanning 338-356.2 $\mathrm{nm}$ are simulated with 6 orders of 

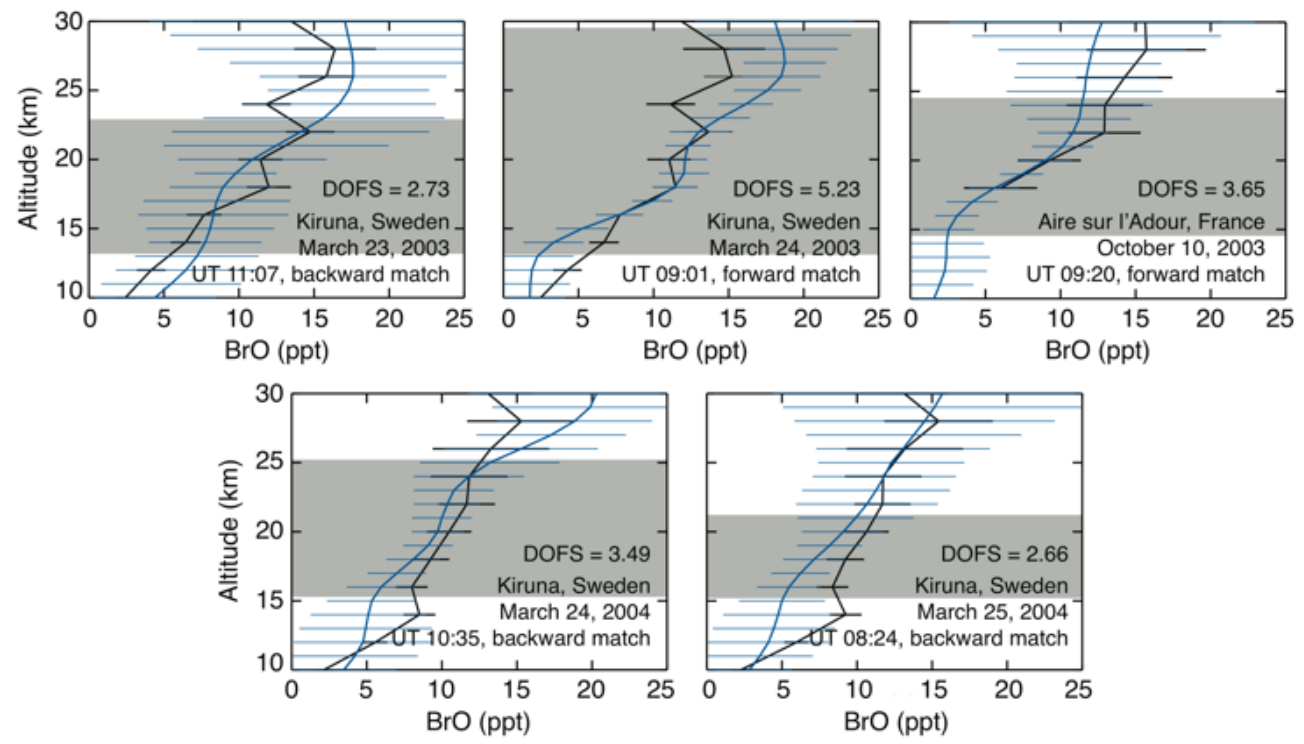

Fig. 2. Retrieved mixing ratios of BrO from SCIAMACHY limb observations (blue) and balloon DOAS observations (black) at Kiruna $\left(67.9^{\circ} \mathrm{N}, 22.1^{\circ} \mathrm{E}\right)$ and Aire sur l'Adour $\left(43.7^{\circ} \mathrm{N}, 0.3^{\circ} \mathrm{W}\right.$ ) (Dorf et al., 2006; Rozanov et al., 2011). Horizontal bars are standard deviations; SCIAMACHY error bars do not include model and model parameter errors (see Sect. 5 for details on model and model parameter errors). SCIAMACHY comparison profiles are selected following Rozanov et al. (2011). Degrees of freedom (DOF) for SCIAMACHY retrievals are shown in each panel. Grey shading indicates the tangent height range of observed SCIAMACHY BrO slant columns used for corresponding retrievals.
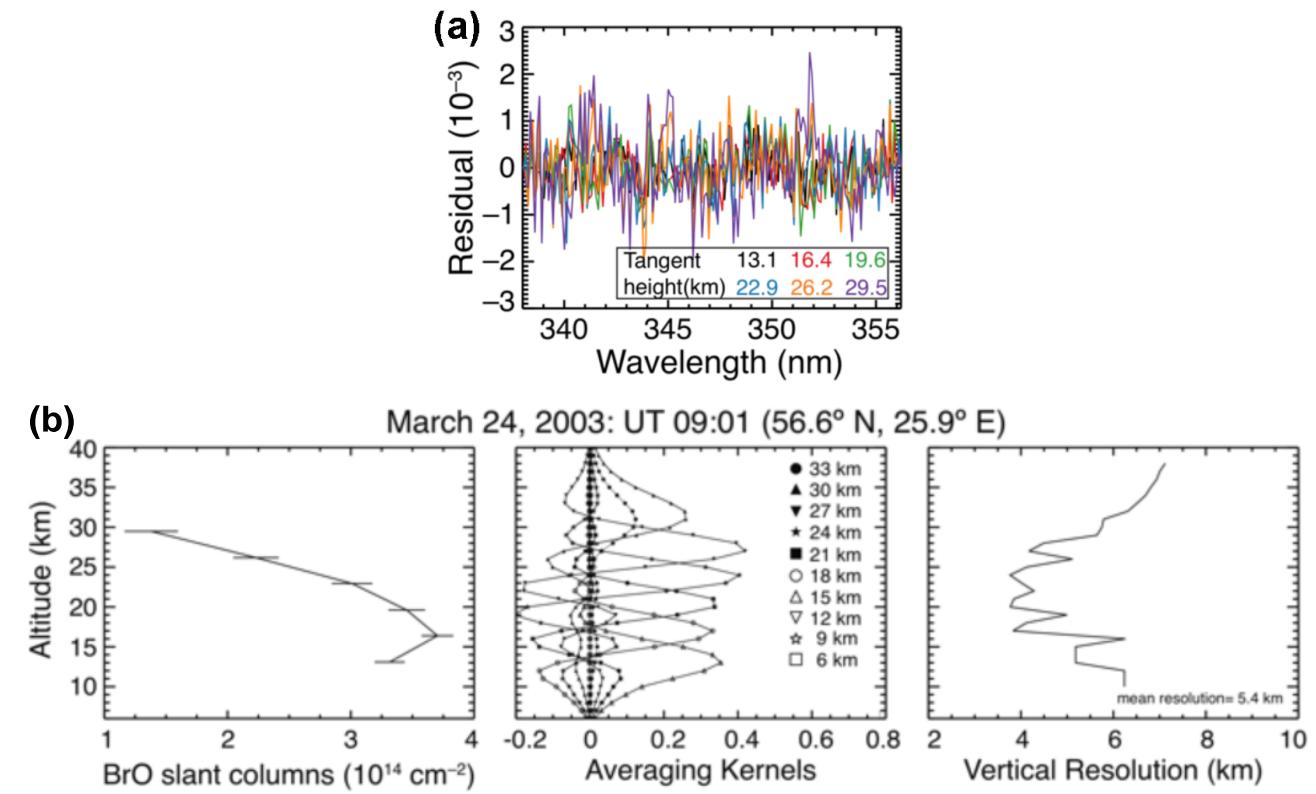

Fig. 3. (a) Fitting residuals for the six BrO slant columns shown in (b). Tangent heights (km) are shown in the key. (b) Retrieved BrO slant columns (left), averaging kernels (middle), and vertical resolution of the retrieval (right) for a SCIAMACHY scan at 09:01 UT, 24 March 2003 (orbit 05558). Standard deviations of the BrO slant column fits are shown with horizontal bars. The columns of the averaging kernel are shown at $3 \mathrm{~km}$ resolution; symbols denote the altitudes corresponding to elements of the state. 


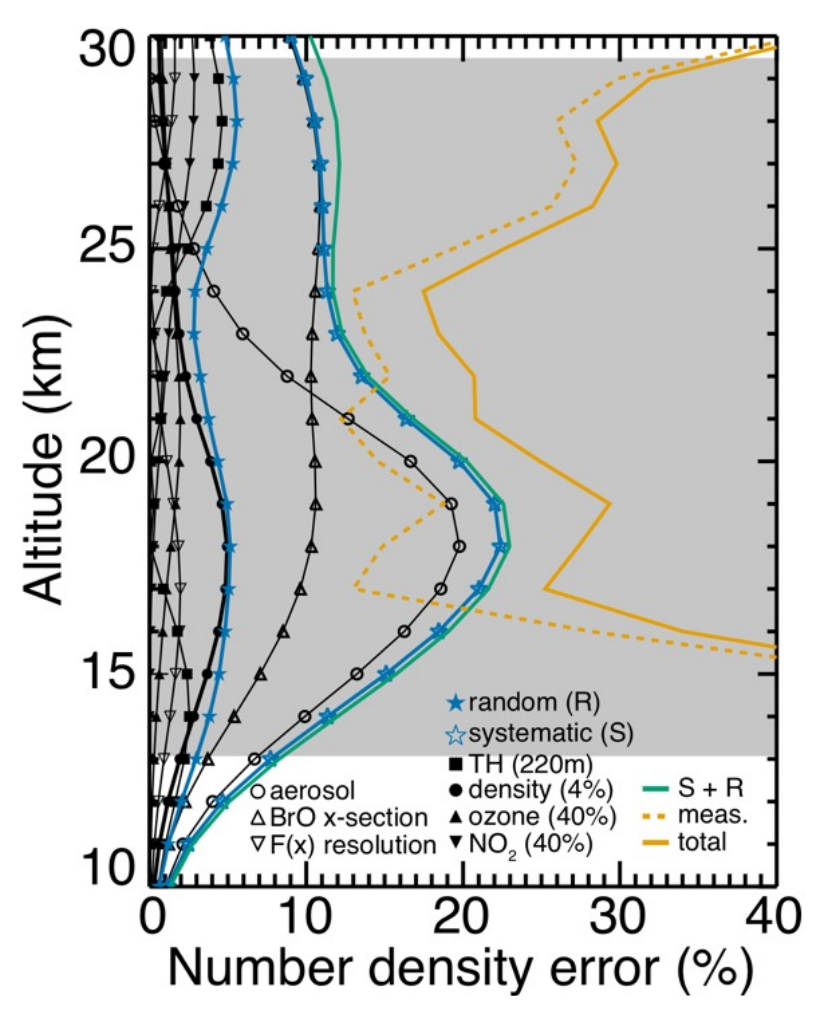

Fig. 4. Error budget for 09:01 UT, 23 March 2003 SCIAMACHY profile retrieval. Random model parameter errors (solid symbols) and systematic model error (open symbols) characterized for our retrieval are shown in black. The total random (filled star) and total systematic errors (open star), summed in quadrature, are both shown in blue. The total model and model parameter error is shown in green. The dashed yellow line represents the measurement error, and the solid yellow line is total error.

Rayleigh scattering at lower spectral resolution $(0.5 \mathrm{~nm})$ than the SCIAMACHY observations $(\sim 0.11 \mathrm{~nm})$ to improve the retrieval speed. After the spectra have been convolved to instrument vertical resolution and sampled on the observation TH-grid (Sect. 3.2), they are then fitted against the same basis functions that were applied to the observations, but on the simulated, low resolution, wavelength grid. We exclude the instrumental corrections ( $\mathrm{US}_{1}, \mathrm{US}_{2}$, low, high, and $\left.\lambda_{\text {shift }}\right)$ and Ring effect in these fits, as they are not treated in the RTM. For simplicity, we perform the fitting of modeled radiances as $\ln \left(\boldsymbol{I}_{0} / \boldsymbol{I}\right)$ in a DOAS linear least squares framework (Platt and Stutz, 2008), as $\lambda_{\text {shift }}$ and other nonlinear terms are unnecessary. Fitting the modeled radiances instead with nonlinear least squares had no significant impact on retrieval results.

\section{Retrieval characterization and comparison to balloon observations}

Figure 2 compares our SCIAMACHY limb retrieval with several independent balloon observations from Kiruna,

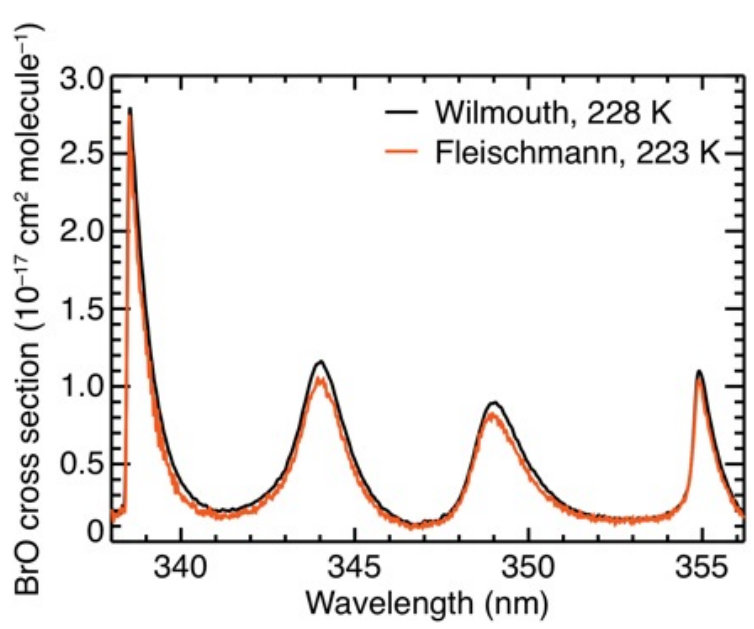

Fig. 5. BrO cross sections from Wilmouth et al. (1998) (black) and Fleischmann et al. (2004) (orange).

Sweden $\left(67.9^{\circ} \mathrm{N}, 22.1^{\circ} \mathrm{E}\right)$, and Aire sur l'Adour, France $\left(43.7^{\circ} \mathrm{N}, 0.3^{\circ} \mathrm{W}\right.$ ) (Dorf et al., 2006). SCIAMACHY limb scans were chosen based on trajectory model calculations performed by Dorf et al. (2006) to match air masses observed by balloon with SCIAMACHY observations, forward or backward in time. The balloon $\mathrm{BrO}$ observations have been translated to the SCIAMACHY overpass times using a photochemical box model (Dorf et al., 2006). The grey shaded area shows the range of SCIAMACHY tangent points included in each inversion (i.e., slant columns that passed data quality filters). The shading only extends to the tangent points of the upper and lower SCDs, with no adjustment for the FOV or the $4 \mathrm{~km}$ correlation length assumption in the a priori. As can be seen from this small set of data, the number of SCDs included in each inversion varies significantly between profiles. Observations between $6 \mathrm{~km}$ and $42 \mathrm{~km}$ tangent points are all considered for each profile inversion, so long as spectra are cloud-free and the fitting RMS is $<10^{-3}$ (Sect. 3.2). Uncertainty for both balloon and SCIAMACHY observations are shown as one standard deviation. SCIAMACHY uncertainties do not include modeling and model parameter errors, which are evaluated in Sect. 5. The $\mathrm{BrO}$ profiles agree within the respective estimated onesigma uncertainties, providing confidence in the validity of our retrieved profiles.

Figure 3a shows example spectral fitting residuals for the 24 March 2003, 09:01 UT retrieval shown in Fig. 2, and Fig. $3 \mathrm{~b}$ further characterizes the retrieval. The mean fitting RMS is $6.3 \times 10^{-4}$. From left to right in Fig. 3b, we show the fitted $\mathrm{BrO}$ slant columns with standard errors, averaging kernels (at $3 \mathrm{~km}$ resolution), and the vertical resolution of the inversion. The averaging kernel, $\mathbf{A}$, provides information on the sensitivity of the a posteriori, $\hat{x}$, to the true atmospheric 


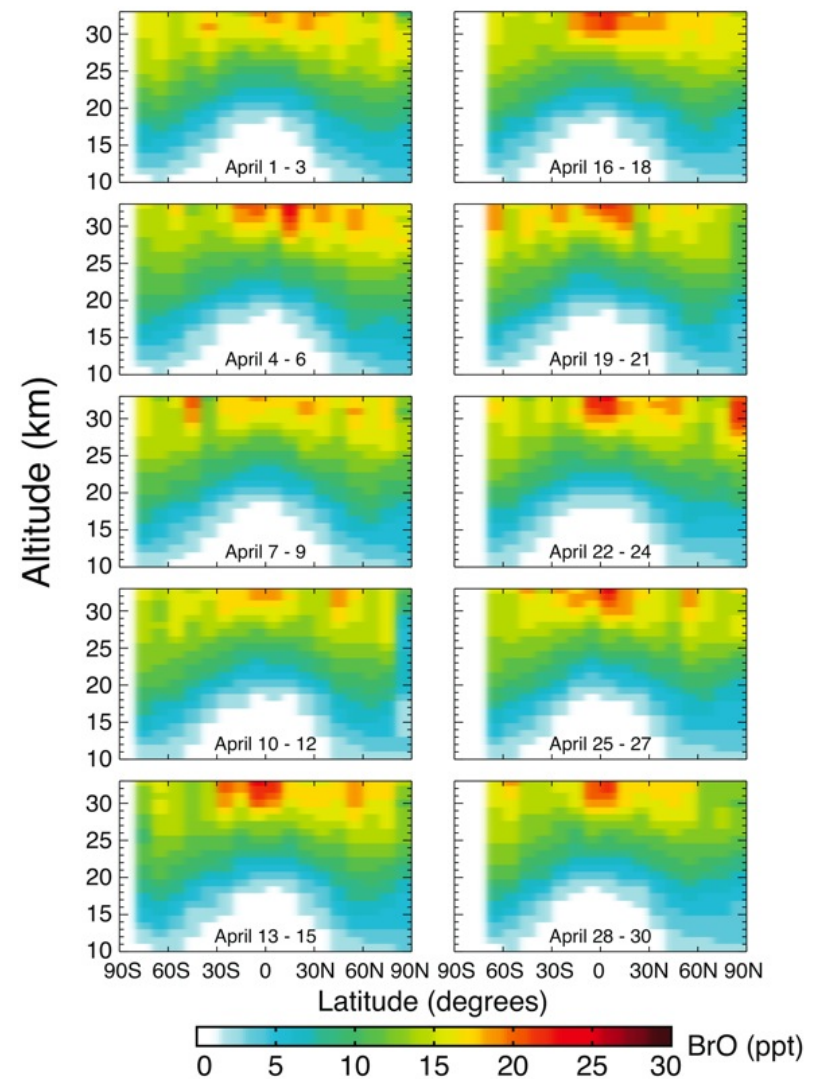

Fig. 6. 3-day zonal mean $\mathrm{BrO}$ (ppt) throughout April 2008. Retrieved profiles with $\chi^{2}>1.4$ were removed.

BrO number density profile (Rodgers, 2000):

$\mathbf{A}=\frac{\partial \hat{x}}{\partial x}=\hat{\mathbf{G}} \mathbf{K}$,

where $\hat{\mathbf{G}}$ is the final iteration of the gain matrix. We calculate the vertical resolution of the retrieval as the FWHM of the averaging kernel profile for each altitude of the state vector to avoid biasing from negative lobes (Rodgers, 2000). The retrieval resolution is between 4 and $6 \mathrm{~km}$ across the measurement range, in good agreement with theoretical expectations for SCIAMACHY (Kaiser, 2001) and other operational retrieval algorithms (Rozanov et al., 2011).

\section{Model error and model parameter error}

Figure 4 shows the sensitivity of retrieved $\mathrm{BrO}$ number density to random error from model parameter selection and systematic error from model assumptions for the 24 March 2003, 09:01 UT retrieval as an example. The SZA and solar azimuth angle (SAA) for this scene are $57.6^{\circ}$ and $39.7^{\circ}$ at $20 \mathrm{~km}$ in altitude. To estimate total model error, we follow an approach similar to that outlined in previous work (Dudhia et al., 2002; Haley et al., 2004; McLinden et al.,

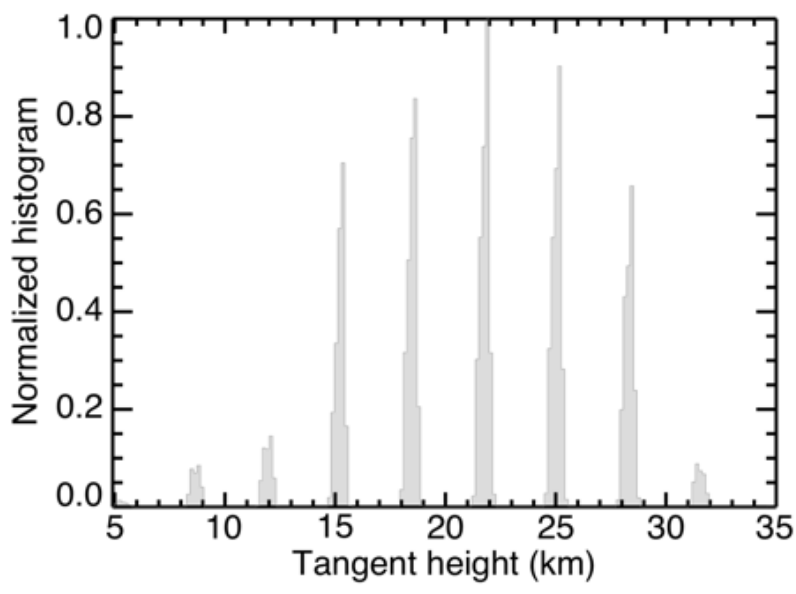

Fig. 7. Histogram of tangent heights for the observations that passed our spectral fitting quality checks and were included in our April $2008 \mathrm{BrO}$ inversions. More observations do not pass quality checks above $25 \mathrm{~km}$ in TH due to the decline in light intensity, and thus signal-to-noise, at these higher altitudes. Above $30 \mathrm{~km}$, the low-light conditions make for a smaller population of useful observations.

2010), where the individual sources of error are treated as independent with an assumed Gaussian uncertainty. Random and systematic errors are shown with open and closed symbols, respectively.

SCIAMACHY engineering tangent heights, provided with Level 1 data, register with \pm 220 m uncertainty (von Savigny et al., 2005). Subtracting $220 \mathrm{~m}$ from the tangent heights results in $<5 \%$ error in retrieved $\mathrm{BrO}$. Sensitivity to ozone and $\mathrm{NO}_{2}$ number density is similarly small. Both profiles were perturbed by $40 \%$ independently, which is within the observed range of standard deviations found in ozonesonde data (Eriksson and Chen, 2002) and limb satellite observations of $\mathrm{NO}_{2}$ (Brohede et al., 2007). The low sensitivity reflects lack of correlation between the modeled $\mathrm{BrO}$ slant column fits, $\boldsymbol{F}\left(x_{i}\right)$, and simultaneously fitted ozone and $\mathrm{NO}_{2}$. The sensitivity increases significantly when decreasing the modeled spectral resolution for $\boldsymbol{F}\left(x_{i}\right)$ from $0.5 \mathrm{~nm}$ to $1 \mathrm{~nm}$, consistent with McLinden et al. (2010). Sensitivities to the surface albedo (0.3), full polarization, and additional orders of scattering in both $\boldsymbol{F}\left(x_{i}\right)$ and $\mathbf{K}$ were found to have insignificant impact, and are not shown in the figure. Uncertainty in air density climatologies is roughly $4 \%$ for these altitudes (Sofieva et al., 2006), and contributes to retrieval error below $23 \mathrm{~km}$ due to enhanced multiple scattering and a greater Rayleigh optical thickness.

Systematic model errors contribute significantly to the total retrieval error. Below $23 \mathrm{~km}$, these errors are dominated by the assumption that aerosols are not present, affecting the retrieved $\mathrm{BrO}$ number densities by $10-20 \%$. With increasing altitude, the error incurred by $10 \%$ uncertainty in $\mathrm{BrO}$ cross section data (see below) becomes the dominant model uncertainty. The aerosol sensitivity is estimated by 

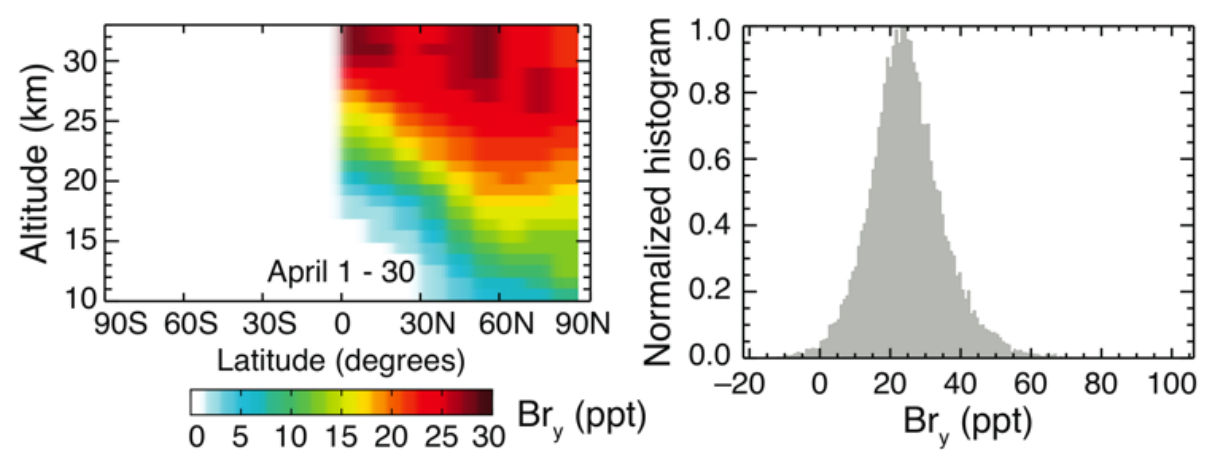

Fig. 8. Zonal mean $\mathrm{Br}_{\mathrm{y}}$ retrieved from SCIAMACHY for April 2008, with $\chi^{2}>1.4$ retrievals removed (left). Right panel represents a histogram of all retrieved $\mathrm{Br}_{\mathrm{y}}$ from April 2008, for state vector elements between $25-36 \mathrm{~km}$ in altitude, with DOF $>0.1$ and $\chi^{2}<1.4$.

including aerosol scattering and absorption in all RTM calculations for both $\boldsymbol{F}\left(x_{i}\right)$ and $\mathbf{K}$, and assuming a background aerosol climatology for the stratosphere from McCormick et al. (1996). BrO cross section error was evaluated by applying Fleischmann et al. (2004) cross sections at $228 \mathrm{~K}$ instead of Wilmouth et al. (1999) at $223 \mathrm{~K}$ for all stages of the inversion algorithm. Both are shown in Fig. 5. Extending the spectral resolution for $\boldsymbol{F}\left(x_{i}\right)$ modeling from $0.5 \mathrm{~nm}$ to the instrument sampling resolution $(\sim 0.11 \mathrm{~nm})$ has insignificant impact on retrieved $\mathrm{BrO}$.

The model and model parameter errors summed in quadrature yield our estimate of total model error for retrieved $\mathrm{BrO}$ within the observation altitude range (grey shading in Fig. 4) as between $10 \%$ and $25 \%$. These are comparable in magnitude to the retrieval noise derived from the OE step. The total error of the retrieval thus spans $20-50 \%$, contingent on the quality of observations included in the inversion.

\section{SCIAMACHY limb BrO observations for April 2008 and implied $\mathrm{Br}_{\mathrm{y}}$}

We applied our retrieval algorithm to all available SCIAMACHY data for April 2008. Figure 6 shows 3-day zonal means of retrieved $\mathrm{BrO}$ mixing ratio from morning observations (i.e., the descending node) only. Profile inversions with $\chi^{2}>1.4$ are excluded; these account for $0.1 \%$ of the total number of limb scans retrieved, and have no impact on the bulk statistics of our results. Cloud filtering and removal of slant columns with RMS $>10^{-3}$ generates the variability in the number of tangent heights included in each profile inversion. Figure 7 shows a histogram of the observation tangent heights used in the retrievals. Most measurement information comes from $15-30 \mathrm{~km}$, with only $9 \%$ of the profile inversions containing information above $30 \mathrm{~km}$. This is due to the lower intensity of light available at tangent heights above $30 \mathrm{~km}$, leaving less signal in these observations.

Our retrievals (Fig. 6) show increasing $\mathrm{BrO}$ mixing ratios with altitude. This mostly reflects the long photochemical lifetimes of the halon and $\mathrm{CH}_{3} \mathrm{Br}$ source gases (Wams- ley et al., 1998). Our retrieved $\mathrm{BrO}$ mixing ratios demonstrate greatest variability close to $30 \mathrm{~km}$ in altitude, resulting from poorer signal to noise at the higher tangent points in SCIAMACHY limb scans (e.g., Rozanov et al., 2011).

We estimate stratospheric $\mathrm{Br}_{\mathrm{y}}$ by applying vertical profiles of the simulated $[\mathrm{BrO}] /\left[\mathrm{Br}_{\mathrm{y}}\right]$ ratio to our retrieved $\mathrm{BrO}$ profiles. The $[\mathrm{BrO}] /\left[\mathrm{Br}_{\mathrm{y}}\right]$ ratios are simulated as described in Salawitch et al. (2010). In this approach, assimilated CFC12 fields are used to determine a baseline stratospheric $\mathrm{Br}_{\mathrm{y}}$ loading, sourced from halons, $\mathrm{CH}_{3} \mathrm{Br}$, and $\mathrm{CH}_{2} \mathrm{Br}_{2}$ (Wamsley et al., 1998). The contribution of $\mathrm{Br}_{\mathrm{y}}$ from VSLS source gases (excluding $\mathrm{CH}_{2} \mathrm{Br}_{2}$ ) was assumed to be an additional $10 \mathrm{ppt}$ (Salawitch et al., 2010), yielding a total mean of 29 ppt stratospheric $\mathrm{Br}_{\mathrm{y}}$. With $\mathrm{Br}_{\mathrm{y}}$ specified, the Whole Atmosphere Community Climate Model (WACCM) is then used to determine the $[\mathrm{BrO}] /\left[\mathrm{Br}_{\mathrm{y}}\right]$ profiles, which are output to specific times and locations corresponding to our April 2008 SCIAMACHY limb scans. This simulation is driven with START08 (Stratosphere-Troposphere Analysis of Regional Transport 2008) meteorology, which is specific to spring 2008 in the Northern Hemisphere. The modeled [BrO]/ $\left[\mathrm{Br}_{\mathrm{y}}\right]$ ratio is nearly independent of $\mathrm{Br}_{\mathrm{y}}$; it depends on the validity of modeled $\left[\mathrm{O}_{3}\right],\left[\mathrm{NO}_{2}\right]$, and chemical kinetic parameters (Salawitch et al., 2010). Uncertainty in simulated $\mathrm{BrO}$ due to chemical kinetics is $30 \%$ globally (Salawitch et al., 2010) and is $21 \%$ for altitudes between $25-36 \mathrm{~km}$, which applies to the $\mathrm{Br}_{\mathrm{y}}$ estimate we present here. This is similar to the $18 \%$ uncertainty estimate for $[\mathrm{BrO}] /\left[\mathrm{Br}_{\mathrm{y}}\right]$ from Hendrick et al. (2008) and is larger than the $\sim 11 \%$ estimate from McLinden et al. (2010).

The left-most panel of Fig. 8 shows a zonal monthly mean and histogram of our April $2008 \mathrm{Br}_{\mathrm{y}}$ estimates, derived by applying modeled $[\mathrm{BrO}] /\left[\mathrm{Br}_{\mathrm{y}}\right]$ to the $\mathrm{BrO}$ profile retrievals. The model estimates of the $[\mathrm{BrO}] /\left[\mathrm{Br}_{\mathrm{y}}\right]$ ratio were only available for the Northern Hemisphere. The zonal mean excludes retrievals with $\chi^{2}>1.4$ ( $0.1 \%$ of the retrieved scans). The right-most panel of Fig. 8 shows a histogram of retrieved $\mathrm{Br}_{\mathrm{y}}$ concentrations where the degrees of rreedom (DOF) of the retrieval are greater than 0.1 the retrieval $>\chi^{2}<1.4$, and 
the altitude is between 25 and $36 \mathrm{~km}$, where most $\mathrm{Br}_{\mathrm{y}}$ source gases have released their bromine. The DOF threshold was applied to reduce a priori biasing; increasing the threshold yielded no significant difference in our results. The varianceweighted mean $\mathrm{Br}_{\mathrm{y}}$ between 25 and $36 \mathrm{~km}$ is $23.5 \mathrm{ppt}$, with a standard deviation in the histogram of $10 \mathrm{ppt}(43 \%)$. This is representative of our total retrieval error, assuming the errors add in quadrature: $30 \%$ mean retrieval noise, $12 \%$ error from forward model error and parameter error (Fig. 4), and $21 \%$ error in the modeled $[\mathrm{BrO}] /\left[\mathrm{Br}_{\mathrm{y}}\right]$ ratios yield a total of $39 \%$ uncertainty.

The retrieval noise becomes negligible $(0.15 \%)$ after taking the variance-weighted mean of all $\mathrm{Br}_{\mathrm{y}}$ estimates in the Fig. 8 histogram. The error for our $\mathrm{Br}_{\mathrm{y}}$ estimate is then dominated by the forward model errors (Fig. 4) and $[\mathrm{BrO}] /\left[\mathrm{Br}_{\mathrm{y}}\right]$ modeling errors. These sources of error sum to $24 \%$ in quadrature. Thus, we estimate $23.5 \pm 6 \mathrm{ppt} \mathrm{Br}$ in the stratosphere for April 2008, implying a contribution of $7 \pm 6 \mathrm{ppt}$ to stratospheric $\mathrm{Br}_{\mathrm{y}}$ from brominated VSLS, and possibly from direct transport of tropospheric $\mathrm{Br}_{\mathrm{y}}$ to the stratosphere. Montzka et al. (2011) recently reviewed the available observational estimates of the stratospheric $\mathrm{Br}_{\mathrm{y}}$ loading, and concluded the central value of contribution from VSLS was $6 \mathrm{ppt}$, with a range of $3-8 \mathrm{ppt}$. Our estimate of $7 \pm 6 \mathrm{ppt}$ is at the high end of this range. The $6 \mathrm{ppt}$ uncertainty is dominated by the chemical kinetics underlying $[\mathrm{BrO}] /\left[\mathrm{Br}_{\mathrm{y}}\right]$ calculations.

\section{Conclusions}

We present a new algorithm for retrieval of $\mathrm{BrO}$ from SCIAMACHY limb radiances, which we characterize and compare to independent balloon observations. Our objective was to use the SCIAMACHY $\mathrm{BrO}$ with simulated $[\mathrm{BrO}] /\left[\mathrm{Br}_{\mathrm{y}}\right]$ to estimate the stratospheric $\mathrm{Br}_{\mathrm{y}}$ loading.

We find reasonable agreement between our SCIAMACHY $\mathrm{BrO}$ retrievals and a small set of independent balloon DOAS measurements (Dorf et al., 2006). Our April 2008 retrievals show increasing $\mathrm{BrO}$ mixing ratio with altitude, consistent with expectations from stratospheric dynamics and photochemistry. Retrieval noise is minimum $(\sim 15 \%)$ between 15 and $25 \mathrm{~km}$, where the signal to noise ratio in spectral observations and the optical sensitivity to the tangent point are both strong. Below this range, the retrieval noise increases due to reduced sensitivity to the greater Rayleigh optical depths. Above, the signal to noise degrades with limb dimming. Forward model and model parameter error is dominated below $23 \mathrm{~km}$ by neglecting stratospheric aerosols in the RTM calculations $(\sim 20 \%)$. Above $23 \mathrm{~km}$, it is dominated by $10 \%$ uncertainty in the $\mathrm{BrO}$ cross sections, with smaller contributions from tangent height pointing uncertainty.

Applying simulated $[\mathrm{BrO}] /\left[\mathrm{Br}_{\mathrm{y}}\right]$ ratios to the retrieved $\mathrm{BrO}$ profiles yields a stratospheric $\mathrm{Br}_{\mathrm{y}}$ loading of $23.5 \pm 6 \mathrm{ppt} \mathrm{Br}$ for April 2008. The estimated contribution to stratospheric bromine from $\mathrm{CH}_{3} \mathrm{Br}$ and halons is $16.5 \mathrm{ppt}$ for April 2008 (Montzka et al., 2011). Hence, our observations suggest that $7 \pm 6 \mathrm{ppt}$ of stratospheric $\mathrm{Br}_{\mathrm{y}}$ is supplied by VSLS bromocarbons (or their decomposition products), which is on the high end of the 3 to 8 ppt value suggested by Montzka et al. (2011). The $\pm 6 \mathrm{ppt}$ error estimate is mostly due to uncertainty in the chemical kinetics used to model the $[\mathrm{BrO}] /\left[\mathrm{Br}_{\mathrm{y}}\right]$ ratio.

Acknowledgements. This research was supported by NASA and the Smithsonian Institution. The authors thank Xiong Liu for discussions and helpful comments on optimal estimation and statistics, Thomas Kurosu for help with spectral fitting, Alexei Rozanov for his helpful comments on SCIAMACHY data and optimal estimation retrievals, and Chris Sioris for help with radiative transfer.

Edited by: A. Lambert

\section{References}

Anderson, J. G., Brune, W. H., Lloyd, S. A., Toohey, D. W., Sander, S. P., Starr, W. L., Loewenstein, M., and Podolske, J. R.: Kinetics of $\mathrm{O}_{3}$ destruction by $\mathrm{ClO}$ and $\mathrm{BrO}$ within the Antarctic vortex: an analysis based on in situ ER-2 data, J. Geophys. Res., 94, 11480-11520, doi:10.1029/JD094iD09p11480, 1989.

Brinckmann, S., Engel, A., Bönisch, H., Quack, B., and Atlas, E.: Short-lived brominated hydrocarbons - observations in the source regions and the tropical tropopause layer, Atmos. Chem. Phys., 12, 1213-1228, doi:10.5194/acp-12-1213-2012, 2012.

Brion, J., Chakir, A., Daumont, D., Malicet, J., and Parisse, C.: High-resolution laboratory absorption cross section of $\mathrm{O}_{3}$, temperature effect, Chem. Phys. Lett., 213, 610-612, 1993.

Brohede, S., McLinden, C. A., Berthet, G., Haley, C. S., Murtagh, D., and Sioris, C. E.: A stratospheric $\mathrm{NO}_{2}$ climatology from Odin/OSIRIS limb-scatter measurements, Can. J. Phys., 85, 1253-1274, doi:10.1139/p07-141, 2007.

Carpenter, L. J. and Liss, P. S.: On temperate sources of bromoform and other reactive organic bromine gases, J. Geophys. Res., 105, 20539-20547, doi:10.1029/2000jd900242, 2000.

Caspar, C. and Chance, K.: GOME wavelength calibration using solar and atmospheric spectra, in: Proc. Third ERS Symposium on Space at the Service of our Environment, ESA SP-414, 3, 609-614, Florence, Italy, 17-21 March, 1997.

Chance, K.: Analysis of BrO measurements from the global ozone monitoring experiment, Geophys. Res. Lett., 25, 3335-3338, doi:10.1029/98gl52359, 1998.

Chance, K. and Kurucz, R. L.: An improved high-resolution solar reference spectrum for earth's atmosphere measurements in the ultraviolet, visible, and near infrared, J. Quant. Spectrosc. Ra., 111, 1289-1295, 2010.

Chance, K. V. and Spurr, R. J. D.: Ring effect studies: rayleigh scattering, including molecular parameters for rotational Raman scattering, and the Fraunhofer spectrum, Appl. Opt., 36, 52245230, 1997. 
Chance, K., Kurosu, T. P., and Sioris, C. E.: Undersampling correction for array detector-based satellite spectrometers, Appl. Opt., 44, 1296-1304, 2005.

Choi, S., Wang, Y., Salawitch, R. J., Canty, T., Joiner, J., Zeng, T., Kurosu, T. P., Chance, K., Richter, A., Huey, L. G., Liao, J., Neuman, J. A., Nowak, J. B., Dibb, J. E., Weinheimer, A. J., Diskin, G., Ryerson, T. B., da Silva, A., Curry, J., Kinnison, D., Tilmes, S., and Levelt, P. F.: Analysis of satellite-derived Arctic tropospheric BrO columns in conjunction with aircraft measurements during ARCTAS and ARCPAC, Atmos. Chem. Phys., 12, 1255-1285, doi:10.5194/acp-12-1255-2012, 2012.

Daumont, D., Brion, J., Charbonnier, J., and Malicet, J.: Ozone UV spectroscopy I: absorption cross-sections at room temperature, J. Atmos. Chem., 15, 145-155, doi:10.1007/bf00053756, 1992.

De Smedt, I., Van Roozendael, M., and Jacobs, T.: Optimization of DOAS settings for BrO fitting from SCIAMACHY nadir spectra - comparison with GOME BrO retrievals, Belgian Institute for Space Aeronomy (IASB-BIRA), Brussels, Belgium, available at: http://bro.aeronomie.be/BIRA_SCIABrO.pdf (last access: 27 October 2012), 2004.

Dorf, M., Bösch, H., Butz, A., Camy-Peyret, C., Chipperfield, M. P., Engel, A., Goutail, F., Grunow, K., Hendrick, F., Hrechanyy, S., Naujokat, B., Pommereau, J.-P., Van Roozendael, M., Sioris, C., Stroh, F., Weidner, F., and Pfeilsticker, K.: Balloon-borne stratospheric $\mathrm{BrO}$ measurements: comparison with Envisat/SCIAMACHY BrO limb profiles, Atmos. Chem. Phys., 6, 2483-2501, doi:10.5194/acp-6-2483-2006, 2006.

Dudhia, A., Jay, V. L., and Rodgers, C. D.: microwindow selection for high-spectral-resolution sounders, Appl. Opt., 41, 36653673, 2002.

Eriksson, P. and Chen, D.: Statistical parameters derived from ozonesonde data of importance for passive remote sensing observations of ozone, Int. J. Remote Sens., 23, 4945-4963, 2002.

Fleischmann, O. C., Hartmann, M., Burrows, J. P., and Orphal, J.: New ultraviolet absorption cross-sections of $\mathrm{BrO}$ at atmospheric temperatures measured by time-windowing Fourier transform spectroscopy, J. Photoch. Photobio. A, 168, 117-132, 2004.

Frieler, K., Rex, M., Salawitch, R. J., Canty, T., Streibel, M., Stimpfle, R. M., Pfeilsticker, K., Dorf, M., Weisenstein, D. K., and Godin-Beekmann, S.: Toward a better quantitative understanding of polar stratospheric ozone loss, Geophys. Res. Lett., 33, L10812, doi:10.1029/2005g1025466, 2006.

Gao, R. S., Fahey, D. W., Salawitch, R. J., Lloyd, S. A., Anderson, D. E., DeMajistre, R., McElroy, C. T., Woodbridge, E. L., Wamsley, R. C., Donnelly, S. G., Del Negro, L. A., Proffitt, M. H., Stimpfle, R. M., Kohn, D. W., Kawa, S. R., Lait, L. R., Loewenstein, M., Podolske, J. R., Keim, E. R., Dye, J. E., Wilson, J. C., and Chan, K. R.: Partitioning of the reactive nitrogen reservoir in the lower stratosphere of the southern hemisphere: observations and modeling, J. Geophys. Res., 102, 3935-3949, doi:10.1029/96jd01967, 1997.

Garcia, R. R. and Solomon, S.: A new numerical model of the middle atmosphere 2. Ozone and related species, J. Geophys. Res., 99, 12937-12951, doi:10.1029/94jd00725, 1994.

Gottwald, M., Bovensmann, H., Lichtenberg, G., Noel, S., von Bargen, A., Slijkhuis, S., Piters, A., Hoogeveen, R., von Savigny, C., Buchwitz, M., Kokhanovsky, A., Richter, A., Rozanov, A., Holzer-Popp, T., Bramstedt, K., Lambert, J.-C., Skupin, J., Wittrock, F., Schrijver, H., and Burrows, J. P.: SCIAMACHY, Mon- itoring the Changing Earth's Atmosphere, DLR, Springer, Heidelberg, doi:10.1007/978-90-481-9896-2, 2011.

Haley, C. S., Brohede, S. M., Sioris, C. E., Griffioen, E., Murtagh, D. P., McDade, I. C., Eriksson, P., Llewellyn, E. J., Bazureau, A., and Goutail, F.: Retrieval of stratospheric $\mathrm{O}_{3}$ and $\mathrm{NO}_{2}$ profiles from Odin Optical Spectrograph and Infrared Imager System (OSIRIS) limb-scattered sunlight measurements, J. Geophys. Res., 109, D16303, doi:10.1029/2004jd004588, 2004.

Hendrick, F., Johnston, P. V., De Mazière, M., Fayt, C., Hermans, C., Kreher, K., Theys, N., Thomas, A., and Van Roozendael, M.: One-decade trend analysis of stratospheric BrO over Harestua $\left(60^{\circ} \mathrm{N}\right)$ and Lauder $\left(45^{\circ} \mathrm{S}\right)$ reveals a decline, Geophys. Res. Lett., 35, L14801, doi:10.1029/2008g1034154, 2008.

Hossaini, R., Chipperfield, M. P., Feng, W., Breider, T. J., Atlas, E., Montzka, S. A., Miller, B. R., Moore, F., and Elkins, J.: The contribution of natural and anthropogenic very short-lived species to stratospheric bromine, Atmos. Chem. Phys., 12, 371-380, doi:10.5194/acp-12-371-2012, 2012.

Kaiser, J. W.: Atmospheric parameter retrieval from UV-vis-NIR limb scattering measurements, $\mathrm{PhD}$ thesis, Univ. of Bremen, Bremen, Germany, 228 pp., 2001.

Kovalenko, L. J., Livesey, N. L., Salawitch, R. J., Camy-Peyret, C., Chipperfield, M. P., Cofield, R. E., Dorf, M., Drouin, B. J., Froidevaux, L., Fuller, R. A., Goutail, F., Jarnot, R. F., Jucks, K., Knosp, B. W., Lambert, A., MacKenzie, I. A., Pfeilsticker, K., Pommereau, J. P., Read, W. G., Santee, M. L., Schwartz, M. J., Snyder, W. V., Stachnik, R., Stek, P. C., Wagner, P. A., and Waters, J. W.: Validation of aura microwave limb sounder BrO observations in the stratosphere, J. Geophys. Res., 112, D24S41, doi:10.1029/2007jd008817, 2007.

Kühl, S., Pukite, J., Deutschmann, T., Platt, U., and Wagner, T.: SCIAMACHY limb measurements of $\mathrm{NO}_{2}, \mathrm{BrO}$ and $\mathrm{OCl} \mathrm{O}$. Retrieval of vertical profiles: algorithm, first results, sensitivity and comparison studies, Adv. Space Res., 42, 1747-1764, 2008.

Laube, J. C., Engel, A., Bönisch, H., Möbius, T., Worton, D. R., Sturges, W. T., Grunow, K., and Schmidt, U.: Contribution of very short-lived organic substances to stratospheric chlorine and bromine in the tropics - a case study, Atmos. Chem. Phys., 8 , 7325-7334, doi:10.5194/acp-8-7325-2008, 2008.

Lindström, P. and Wedin, P.-Å.: Methods and Software for Nonlinear Least Squares Problems, Inst. of Information Processing, University of Umeå, Umeå, Sweden, 1988.

Liu, X., Chance, K., Sioris, C. E., and Kurosu, T. P.: Impact of using different ozone cross sections on ozone profile retrievals from Global Ozone Monitoring Experiment (GOME) ultraviolet measurements, Atmos. Chem. Phys., 7, 3571-3578, doi:10.5194/acp7-3571-2007, 2007.

Malicet, J., Daumont, D., Charbonnier, J., Parisse, C., Chakir, A., and Brion, J.: Ozone UV spectroscopy, II. absorption crosssections and temperature dependence, J. Atmos. Chem., 21, 263273, doi:10.1007/bf00696758, 1995.

McCormick, M. P., Wang, P. H., and Pitts, M. C.: Background stratospheric aerosol and polar stratospheric cloud reference models, Adv. Space Res., 18, 155-177, 1996.

McLinden, C. A., Olsen, S. C., Hannegan, B., Wild, O., Prather, M. J., and Sundet, J.: Stratospheric ozone in 3-D models: a simple chemistry and the cross-tropopause flux, J. Geophys. Res., 105, 14653-14665, 2000. 
McLinden, C. A., McConnell, J. C., Griffioen, E., and McElroy, C. T.: A vector radiative-transfer model for the Odin/OSIRIS project, Can. J. Phys., 80, 375-393, doi:10.1139/p01-156, 2002.

McLinden, C. A., Haley, C. S., and Sioris, C. E.: Diurnal effects in limb scatter observations, J. Geophys. Res., 111, D14302, doi:10.1029/2005jd006628, 2006.

McLinden, C. A., Haley, C. S., Lloyd, N. D., Hendrick, F., Rozanov, A., Sinnhuber, B. M., Goutail, F., Degenstein, D. A., Llewellyn, E. J., Sioris, C. E., Van Roozendael, M., Pommereau, J. P., Lotz, W., and Burrows, J. P.: Odin/OSIRIS observations of stratospheric BrO: retrieval methodology, climatology, and inferred bry, J. Geophys. Res., 115, D15308, doi:10.1029/2009jd012488, 2010.

McPeters, R. D., Labow, G. J., and Logan, J. A.: Ozone climatological profiles for satellite retrieval algorithms, J. Geophys. Res., 112, D05308, doi:10.1029/2005jd006823, 2007.

Montzka, S. A., Reimann, S. (Coordinating Lead Authors), Engel, A., Krüger, K., O’Doherty, S., Sturges, W. T., Blake, D. R., Dorf, M., Fraser, P., Froidevaux, L., Jucks, K. W., Kreher, K., Kurylo, M. J., Mellouki, A., Miller, J., Nielsen, O.-J., Orkin, V. L., Prinn, R. G., Rhew, R., Santee, M. L., Stohl, A., and Verdonik, D.: Ozone-Depleting Substances (OESs) and Related Chemicals, World Meteorological Organization, Geneva, Switzerland, 516 pp., 2011.

Platt, U. and Stutz, J.: Differential Optical Absorption Spectroscopy: Principles and Applications, Springer Verlag, Heidelberg, Germany, 2008.

Prather, M.: Catastrophic loss of stratospheric ozone in dense volcanic clouds, J. Geophys. Res., 97, 10187-10191, doi:10.1029/92jd00845, 1992.

Rodgers, C. D.: Inverse Methods for Atmospheric Sounding: Theory and Practice, 1st Edn., World Sci., River Edge, N.J., 2000.

Rozanov, A., Bovensmann, H., Bracher, A., Hrechanyy, S., Rozanov, V., Sinnhuber, M., Stroh, F., and Burrows, J. P.: $\mathrm{NO}_{2}$ and $\mathrm{BrO}$ vertical profile retrieval from SCIAMACHY limb measurements: sensitivity studies, Adv. Space Res., 36, 846-854, 2005.

Rozanov, A., Kühl, S., Doicu, A., McLinden, C., Puksite, J., Bovensmann, H., Burrows, J. P., Deutschmann, T., Dorf, M., Goutail, F., Grunow, K., Hendrick, F., von Hobe, M., Hrechanyy, S., Lichtenberg, G., Pfeilsticker, K., Pommereau, J. P., Van Roozendael, M., Stroh, F., and Wagner, T.: BrO vertical distributions from SCIAMACHY limb measurements: comparison of algorithms and retrieval results, Atmos. Meas. Tech., 4, 1319-1359, doi:10.5194/amt-4-1319-2011, 2011.

Salawitch, R. J., Wofsy, S. C., Gottlieb, E. W., Lait, L. R., Newman, P. A., Schoeberl, M. R., Loewenstein, M., Podolske, J. R., Strahan, S. E., Proffitt, M. H., Webster, C. R., May, R. D., Fahey, D. W., Baumgardner, D., Dye, J. E., Wilson, J. C., Kelly, K. K., Elkins, J. W., Chan, K. R., and Anderson, J. G.: Chemical loss of ozone in the Arctic Polar Vortex in the winter of 1991-1992, Science, 261, 1146-1149, 1993.

Salawitch, R. J., Weisenstein, D. K., Kovalenko, L. J., Sioris, C. E., Wennberg, P. O., Chance, K., Ko, M. K. W., and McLinden, C. A.: Sensitivity of ozone to bromine in the lower stratosphere, Geophys. Res. Lett., 32, L05811, doi:10.1029/2004g1021504, 2005.

Salawitch, R. J., Canty, T., Kurosu, T., Chance, K., Liang, Q., da Silva, A., Pawson, S., Nielsen, J. E., Rodriguez, J. M., Bhar- tia, P. K., Liu, X., Huey, L. G., Liao, J., Stickel, R. E., Tanner, D. J., Dibb, J. E., Simpson, W. R., Donohoue, D., Weinheimer, A., Flocke, F., Knapp, D., Montzka, D., Neuman, J. A., Nowak, J. B., Ryerson, T. B., Oltmans, S., Blake, D. R., Atlas, E. L., Kinnison, D. E., Tilmes, S., Pan, L. L., Hendrick, F., Van Roozendael, M., Kreher, K., Johnston, P. V., Gao, R. S., Johnson, B., Bui, T. P., Chen, G., Pierce, R. B., Crawford, J. H., and Jacob, D. J.: A new interpretation of total column BrO during Arctic spring, Geophys. Res. Lett., 37, L21805, doi:10.1029/2010g1043798, 2010.

Sinnhuber, B. M., Rozanov, A., Sheode, N., Afe, O. T., Richter, A., Sinnhuber, M., Wittrock, F., Burrows, J. P., Stiller, G. P., von Clarmann, T., and Linden, A.: Global observations of stratospheric bromine monoxide from SCIAMACHY, Geophys. Res. Lett., 32, L20810, doi:10.1029/2005g1023839, 2005.

Sioris, C. E., Kovalenko, L. J., McLinden, C. A., Salawitch, R. J., Van Roozendael, M., Goutail, F., Dorf, M., Pfeilsticker, K., Chance, K., von Savigny, C., Liu, X., Kurosu, T. P., Pommereau, J. P., Bösch, H., and Frerick, J.: Latitudinal and vertical distribution of bromine monoxide in the lower stratosphere from scanning imaging absorption spectrometer for atmospheric chartography limb scattering measurements, J. Geophys. Res., 111, D14301, doi:10.1029/2005jd006479, 2006.

Sofieva, V., Tamminen, J., Kyrölä, E., Team, G. C. A. L. V. A. L., Foelsche, U., Kirchengast, G., and Steiner, A.: Modeling errors of GOMOS measurements: a sensitivity study, in: Atmosphere and Climate, Springer, Berlin, 67-78, 2006.

Tarpley, D.: NMC Upper Air Derived Data (FIFE), Data set, in: Collected Data of the First ISLSCP Field Experiment, Vol. 1: Surface Observations and Non-Image Data Sets, edited by: Strebel, D. E., Landis, D. R., Huemmrich, K. F., and Meeson, B. W., doi:10.3334/ORNLDAAC/57, 1994.

Theys, N., Van Roozendael, M., Hendrick, F., Yang, X., De Smedt, I., Richter, A., Begoin, M., Errera, Q., Johnston, P. V., Kreher, K., and De Mazière, M.: Global observations of tropospheric BrO columns using GOME-2 satellite data, Atmos. Chem. Phys., 11, 1791-1811, doi:10.5194/acp-11-1791-2011, 2011.

Vandaele, A. C., Hermans, C., Simon, P. C., Carleer, M., Colin, R., Fally, S., Mérienne, M. F., Jenouvrier, A., and Coquart, B.: Measurements of the $\mathrm{NO}_{2}$ absorption cross-section from $42000 \mathrm{~cm}^{-1}$ to $10000 \mathrm{~cm}^{-1}(238-1000 \mathrm{~nm})$ at $220 \mathrm{~K}$ and 294 K, J. Quant. Spectrosc. Ra., 59, 171-184, 1998.

von Savigny, C., Ulasi, E. P., Eichmann, K.-U., Bovensmann, H., and Burrows, J. P.: Detection and mapping of polar stratospheric clouds using limb scattering observations, Atmos. Chem. Phys., 5, 3071-3079, doi:10.5194/acp-5-3071-2005, 2005.

Wamsley, P. R., Elkins, J. W., Fahey, D. W., Dutton, G. S., Volk, C. M., Myers, R. C., Montzka, S. A., Butler, J. H., Clarke, A. D., Fraser, P. J., Steele, L. P., Lucarelli, M. P., Atlas, E. L., Schauffler, S. M., Blake, D. R., Rowland, F. S., Sturges, W. T., Lee, J. M., Penkett, S. A., Engel, A., Stimpfle, R. M., Chan, K. R., Weisenstein, D. K., Ko, M. K. W., and Salawitch, R. J.: Distribution of halon-1211 in the upper troposphere and lower stratosphere and the 1994 total bromine budget, J. Geophys. Res., 103, 1513-1526, doi:10.1029/97jd02466, 1998.

Wennberg, P. O., Cohen, R. C., Stimpfle, R. M., Koplow, J. P., Anderson, J. G., Salawitch, R. J., Fahey, D. W., Woodbridge, E. L., 
Keim, E. R., Gao, R. S., Webster, C. R., May, R. D., Toohey, D. W., Avallone, L. M., Proffitt, M. H., Loewenstein, M., Podolske, J. R., Chan, K. R., and Wofsy, S. C.: Removal of Stratospheric $\mathrm{O}_{3}$ by Radicals: In situ measurements of $\mathrm{OH}, \mathrm{HO}_{2}$, $\mathrm{NO}, \mathrm{NO}_{2}, \mathrm{ClO}$, and BrO, Science, 266, 398-404, 1994.
Wilmouth, D. M., Hanisco, T. F., Donahue, N. M., and Anderson, J. G.: Fourier transform ultraviolet spectroscopy of the A $2 \Pi 3 / 2 \leftarrow X 2 \Pi 3 / 2$ transition of BrO, J. Phys. Chem. A, 103, 8935-8945, doi:10.1021/jp991651o, 1999. 